\title{
Isolation and characterization of brain-specific transglutaminases from rat
}

\author{
Sahng Jung Kwak ${ }^{3}$, Soo Youl Kim, \\ Yong Sik Kim ${ }^{1}$, Kye Yong Song ${ }^{2}$, In Gyu Kim and \\ Sang Chul Park ${ }^{1,4}$ \\ 1 Departments of Biochemistry and Pharmacology, Seoul National University, College \\ of Medicine, Seoul 110-799, Korea \\ 2 Department of Pathology, Chung Ang University College of Medicine, Seoul, Korea \\ 3 Department of Biochemistry, Dankook University College of Medicine \\ 4 Corresponding Author: Tel, 82-2-740-8244; Fax, 82-2-744-4534
}

Accepted 12 August 1998

Abbreviations: TGase, transglutaminases; FBS, fetal bovine serum
Keywords: TGase NI, TGaase NII, brain, rat, localization Introduction

The transglutaminases (TGase), protein crosslinking enzymes, has been suspected to be associated with the pathogenesis of neurodegenerative diseases, notably of Altzheimer's disease, where the crosslinkings of neurofilaments (Selkoe et al., 1982), microtubule-associated tau proteins (Dudek and Johnson, 1993) or amyloid $\beta$ protein $\left(\beta_{4}\right)$ (lkura et al., 1993, Rasmussen et al., 1994) were probably involved. And the recent findings that TGase-mediated formation of cytokine dimers such as interleukin 2 (Eitan and Schwartz, 1993) and midkine (Mahony et al., 1996) could affect the neuronal function suggest strongly the significant roles of the enzyme in brain.

Moreover, it was found that Huntington's disease and several other neurodegenerative disorders are associated with CAG repeat expansion encoding a polyglutamine tract (Ross, 1995). The glutamine residue can be possibly involved in formation of cross-linked supramolecular structure both within and between proteins through reactions catalyzed by TGase. Relevantly, it would be natural to assume the participation of the enzyme in the pathogenesis of neurodegenerative disorders.

In addition, the enzyme has GTP-binding and GTPase activity (Lee et al., 1989), related with signal transduction system as Gh protein between $\alpha_{1}$ adrenergic receptor and phospholipase $\mathrm{C}$, influencing the neural functions (Nakaoka, 1994, Whang et al., 1995). Therefore, the regulation of TGase activity either as a crosslinker or as a signal transducer would be very important in functional, developmental and pathogenetic aspects of nervous system.

The presence of transglutaminase $\mathrm{C}$ (TGase $\mathrm{C}$ ) in the brain has been suggested but debated because of low activity and poor evidence of identity. Possible existence of other types of TGase has been implied from the studies of tetanus-toxin activatable synaptic TGase (Facchiano et al., 1993), substrate-specificity to IL-2 (Schwartz, 1993), and acetylcholine receptor aggregation (Hucho and Bandini, 1990), which showed a quite distinct property different from TGase C. Therefore, it is necessary to investigate the identity and properties of brain TGase. In the present study, we tried to isolate and characterize TGases from rat brain tissues and to elucidate their distribution.

\section{Materials and Methods}




\section{Materials}

$\left[1,4-{ }^{14} \mathrm{C}\right]$ putrescine hydrochloride $(118 \mathrm{mCi} / \mathrm{mmol})$ was purchased from Amersham Corp.; Phenylmethyl sulfonyl fluoride, aprotinin, dansylcadaverine and dithiothreitol from Sigma; benzamidine hydrochloride from Aldrich; dispase, proteinase $\mathrm{K}$, trypsin, chymotrypsin and leupeptin from Boehringer Manheim; Q-sepharose, DEAE-sephacel, $\mathrm{CM}$ cellulose from Pharmacia Fine Chemical Co. Other chemicals of analytical grade were obtained from the local commercial sources.

\section{Methods}

\section{TGase assay}

A modification of a published assay (Folk and Chung, 1985) was used. Reactions were conducted at $37^{\circ} \mathrm{C}$ in $0.5 \mathrm{ml}$ of $0.1 \mathrm{M}$ Tris acetate buffer, $\mathrm{pH} 7.5$, containing $1 \%$ dimethylated casein, $1 \mathrm{mM} \mathrm{CaCl}, 0.5 \%$ Lubrol PX, $5 \mathrm{mM}$ DTT, $0.15 \mathrm{M} \mathrm{NaCl}, 0.5 \mu \mathrm{Ci}$ of $\left[1,4-{ }^{14} \mathrm{C}\right]$ putrescine, and $50 \mu \mathrm{l}$ portions of enzyme solution. Assays were carried out for $1 \mathrm{~h}$ and were terminated by the addition of $4 \mathrm{ml}$ of cold $7.5 \%$ trichloroacetic acid. After $30 \mathrm{~min}$ in the cold, the precipitates were collected on GF/A glass filters (Whatmann) and washed with several $30 \mathrm{ml}$ portions of $5 \%$ trichloroacetic acid. The radioactivity was measured in a Beckman liquid scintillation spectrometer. Enzyme activity is expressed as cpm incorporated/h.

\section{Preparation of TGase from rat brain}

The brains were collected from 100 heads of SpragueDawley male rats, which were homogenized in buffer $A$ (50 mM Tris-acetate, $1 \mathrm{mM}$ EDTA, I mM PMSF, $1 \mathrm{mM}$ benzamidine, $2 \mathrm{mg}$ of leupeptin and 200 trypsin inhibitor unit of aprotinin/liter, $\mathrm{pH} 7.5$ ) by polytron homogenizer (Brinkman Instruments). The homogenate was centrifuged for 1 hour at $10,000 \mathrm{~g}$ and $4^{\circ} \mathrm{C}$. The supernatant was filtered by cheese cloth. The filtrate was subjected to sequential column chromatography and gel filtration. The samples were loaded on DEAE-Sephacel column $(7.5 \times 14 \mathrm{~cm})$, equilibrated with buffer $A$. The fractions with high transglutaminase activity eluted by $\mathrm{NaCl}$ concentration gradient from 0 to $1.0 \mathrm{M}$ were combined. The combined fractions after dialysis against buffer $B$ (50 $\mathrm{mM}$ Tris-acetate, $1 \mathrm{mM}$ EDTA, $\mathrm{pH}$ 7.5) were loaded on CM-cellulase column $(3.2 \times 15 \mathrm{~cm})$. When the CMcellulose column was eluted with Buffer $B$, the enzyme activity was found in the washing fractions. The pooled enzyme fractions were dialyzed against Buffer $B$, and loaded on Q-Sepharose column $(2.6 \times 10 \mathrm{~cm})$. The loaded enzyme fractions on $Q$ Sepharose column were eluted by $\mathrm{NaCl}$ concentration gradient from 0 to $0.6 \mathrm{M}$. The two peaks of the enzyme activity were separately pooled and were subjected to 2 nd Q-sepharose column chromatography, respectively. The enzymic fractions after 2nd Q-sepharose column were concentrated, separately by Amicon conflow 10, which were designated as $\mathrm{NI}$ and $\mathrm{NII}$ fractions. The concentrated samples were dialyzed against buffer $A$, which were subjected to FPLC gel filtration (Waters Co.). The samples were eluted with Buffer C (50 mM Tris-acetate, $1 \mathrm{mM}$ EDTA, $0.15 \mathrm{M} \mathrm{NaCl}, \mathrm{pH}$ 7.5) using Glass SW 300 gel filtration column. The fractions of high enzymic activities were collected and concentrated in Amicon conflow 10.

\section{Properties of the enzyme}

The biochemical characteristics of the enzyme fraction $\mathrm{NI}$ and NII were studied for $K_{m}$ value toward putrescine, and $\mathrm{Ca}^{2+}$ requirement. For the sensitivity to protease, batches of TGase $\mathrm{NI}$ and NII were incubated with 0.2 units of dispase (Boehringer-Mannheim) $/ \mathrm{ml}$ of Tris-acetate buffer $(\mathrm{pH} 7.5,0.05 \mathrm{M})$ or with trypsin in a similar manner. The sensitivity of the respective enzyme to ethanol was determined by addition of ethanol to the reaction mixture during the incubation time.

\section{Antibody preparation}

Antibodies to purified TGase NI or NII were prepared in rabbits. The enzyme ( $0.1 \mathrm{mg}$ in $1 \mathrm{ml}$ PBS) was emulsified with an equal volume of Freund's complete adjuvant and administered intramuscularly at the area near the foreleg lymph nodes. The same procedure was followed 2 weeks later. After two additional weeks, emulsified antigen solution composed of $0.1 \mathrm{mg}$ of enzyme in $1.0 \mathrm{ml}$ PBS and an equal volume of Freund's incomplete adjuvant was administered in a similar fashion. The rabbit was bled 2 weeks after the last injection and the antiserum was stored at $-20^{\circ} \mathrm{C}$.

\section{Immunoblot analysis}

Protein samples were transferred electrophoretically onto nitrocellulose strips. These nitrocellulose strips were saturated with $3 \%$ gelatin in $20 \mathrm{mM}$ Tris, $\mathrm{pH} 7.4$ containing $0.5 \mathrm{M} \mathrm{NaCl}$ by incubation for $1 \mathrm{~h}$ at room temperature. The strips were then washed with this buffer containing $0.05 \%$ Tween 20 and incubated overnight with immunoglobulin in a $1 \%$ gelatin solution. The strips were washed with the Tween-containing buffer and further incubated for $1 \mathrm{hr}$ with horse radish peroxidase-conjugated protein A (Bio-Rad) (1:2000 dilution). The strips were washed again with the Tween-containing buffer, and the blots were developed for 2-15 min with a 4 chlor-1-naphthol/ hydrogen peroxide reagent. After the completion of the reaction, the strips were washed with distilled water and photographed.

\section{Immunocytochemical analysis}

For the immunocytochemical analysis, the midbrain was dissected out from the fetal brain of 15 days of pregnant rat. The nerve cells were collected by centrifugation and pipetting procedure, which were cultured in DMEM/F12 
(1:1) medium including 10\% FBS, 2 mM glutamine, 50 $\mathrm{IU} / \mathrm{ml}$ penicillin and $50 \mu \mathrm{g} / \mathrm{ml}$ streptomycin. The 10,000 20,000 cells were cultured on Aclar coverslip. To inhibit the growth of astrocyte, the defined media without FBS was used. After 20 hours of incubation, the media was shifted to FBS-free media but containing $20 \mu \mathrm{g} / \mathrm{ml}$ insulin, $100 \mu \mathrm{g} / \mathrm{ml}$ transferrin, $20 \mathrm{mM}$ selenium, $0.1 \mathrm{M}$ putrescine, $1 \mathrm{mM}$ pyruvate, $2 \mathrm{mM}$ glutamine, $50 \mu \mathrm{g} / \mathrm{ml}$ penicilline, $50 \mu \mathrm{g} / \mathrm{ml}$ streptomycin and $0.5 \%$ glucose. PC12 and C6 glioma cell lines were maintained in 10\% FBS-DMEM. All the plastic dishes were coated with poly-L-lysine (10 $\mu \mathrm{g} / \mathrm{ml})$. After culture, the cells were fixed for 30 minutes with $4 \%$ paraformaldehyde and washed twice with PBS buffer. Sections were then incubated for $45 \mathrm{~min}$ with I: 100 dilution of rabbit polyclonal antiTGase NI, antiTGase $\mathrm{NII}$ or antiTGase C antibody, respectively. The slides were washed in PBS and incubated with a second antibody consisting of biotin-conjugated swine antirabbit immunoglobulin (LSAB kit, DAKO) and normal swine serum for $30 \mathrm{~min}$, followed by a TBS wash. Finally, the sections were incubated with HRP-conjugated avidin biotin complex (ABC complex). Antibody localization was performed using diaminobenzidine reaction. Negative

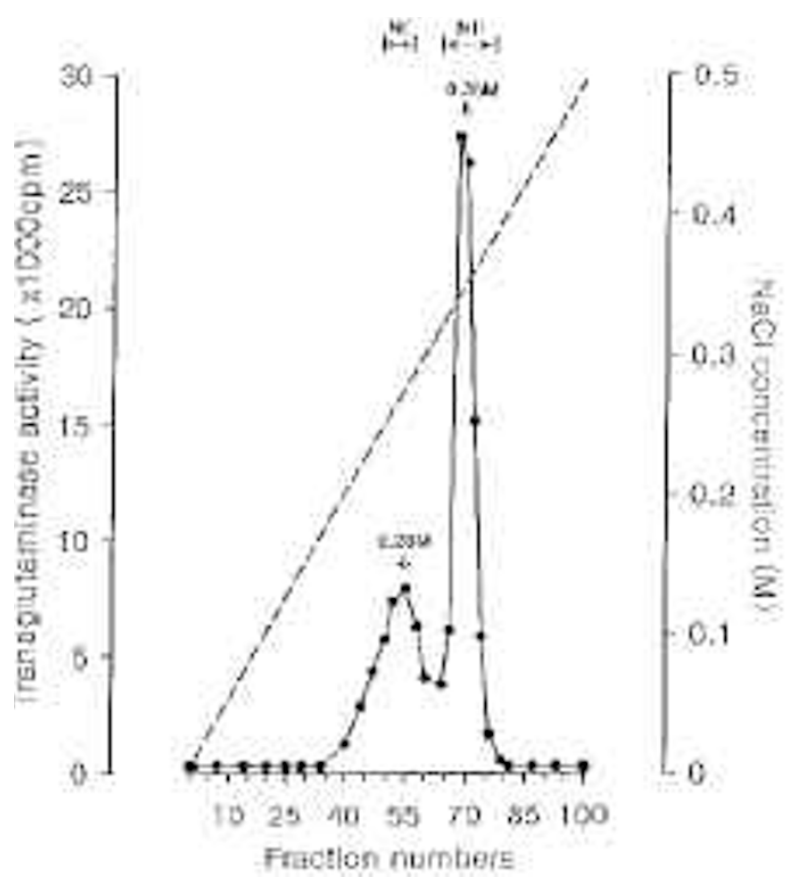

Figure 1. The elution profile of TGase activity through Q-Sepharose column chromatography. The enzyme preparation purified up tp first Q-Sepharose column chromatography was dialyzed against buffer $B$, and was rechromatographed on the same column. Two peaks of enzyme activity were separated and they were designated as $\mathrm{NI}$ and $\mathrm{NII}$. Closed dotted line indicates the enzyme activity and broken line for $\mathrm{NaCl}$ concentration. TGase activity was measured according to the method describe in Material and Method. controls consist of substitution of primary antibody with non-cross reacting rabbit serum.

\section{Results}

\section{Enzyme isolation from rat brain}

By the sequential treatments of homogenization, chromatography on DEAE-Sephacel, CM-cellulose, double Q-sepharose and the final FPLC gel filtration, the transglutaminase activities from rat brain tissues had been found in two different fractions. The salt gradient on DEAESephacel chromatography eluted the major TGase activity at $0.35 \mathrm{M} \mathrm{NaCl}$, while minor faction at $0.28 \mathrm{M} \mathrm{NaCl}$. After dialysis of the combined fractions, $\mathrm{pH}$ of the mixture was adjusted to 6.0 to eliminate other denatured proteins by centrifugation. The $\mathrm{CM}$-cellulose chromatography indicated the elution profile of the enzymic activities in the washing fractions, indicating the low pl value of the brain TGase. After Q-sepharose chromatography, the enzymic activities were observed to be eluted at $0.28 \mathrm{M}$ and $0.35 \mathrm{M}$ of $\mathrm{NaCl}$ concentration (Figure 1). The respectively pooled fractions were designated as TGase $\mathrm{NI}$ with lower $\mathrm{NaCl}$ elution profile and TGase NII with higher $\mathrm{NaCl}$ elution profile fraction. Each fraction was again purified by FPLC gel filtration, which was concentrated by Amicon conflow 10.

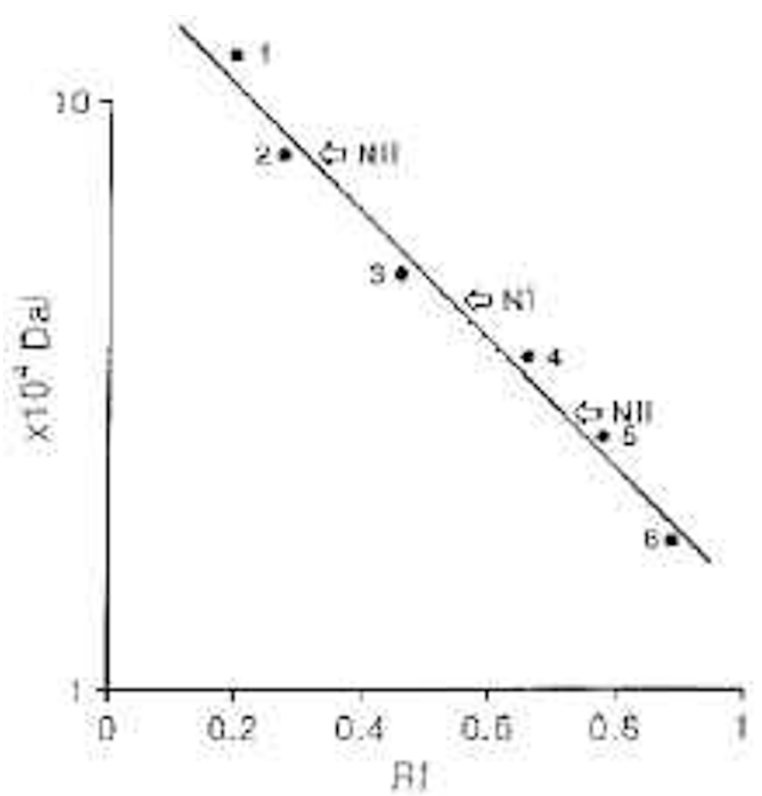

Figure 2. Molecular sizes of TGase NI and NII by SDS-polyacrylamide gel electrophoresis Number 1 indicates phosphorylase $B(\mathrm{mw}$.); 2 , bovine serum albumin (mw.); 3, ovalbumin (mw.); 4, carbonic anhydrase (mw.); 5, soybean trypsin inhibitor $(\mathrm{mw}$ ); 6 , lysozyme (mw.); fraction NI, TGase NI (mw. = $45 \mathrm{kDa})$; NII, TGase NII (mw. = $29 \mathrm{kDa})$ 


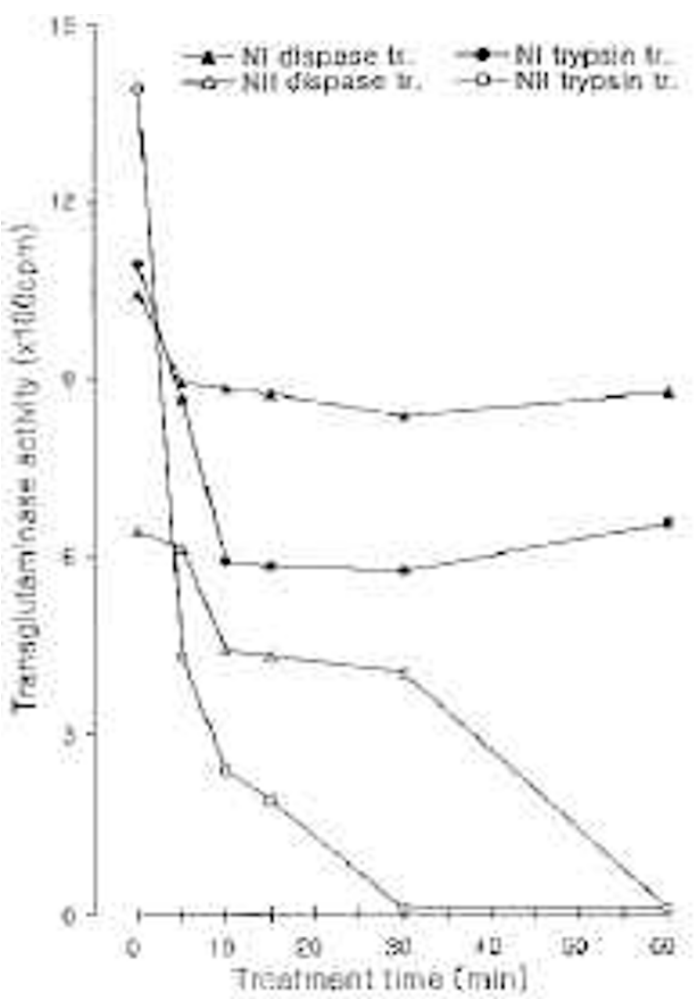

Figure 3. Sensitivity of partially purified TGase toward dispase and trypsin treatment. Pratially purified NI and NII TGase was treated with 0.2 units each of dspase ( $\Delta$ for $\mathrm{N}$ and $\triangle$ for NII) or trypsin ( $\bigcirc$ for $\mathrm{NI}$ and $\bigcirc$ for NII), and the remaining enzyme activities were determined.

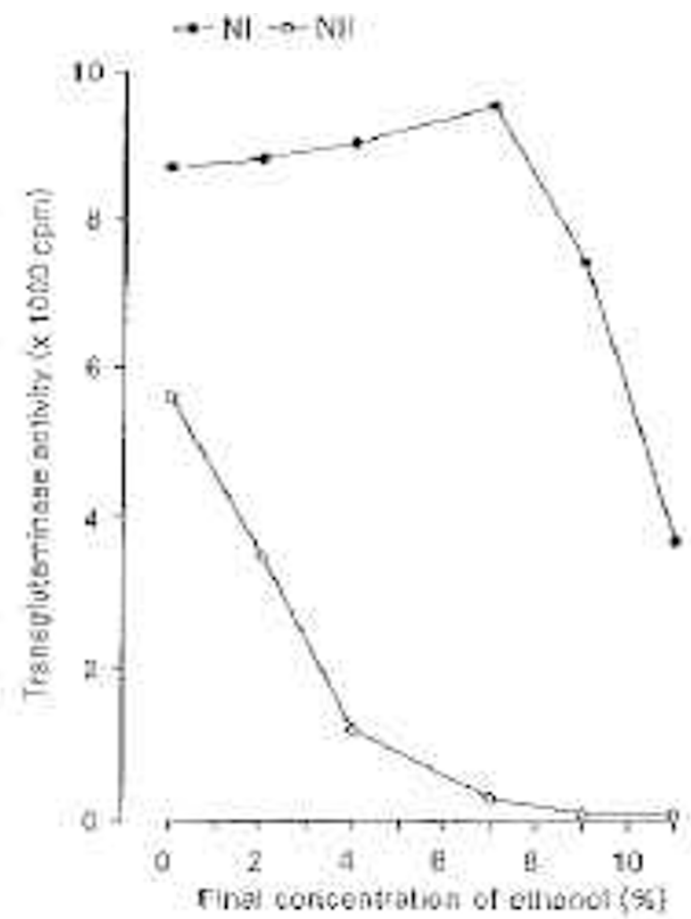

Figure 5. Effect of ethanol on partially purified brain TGase. TGase NI (closed circle) and $\mathrm{NII}$ (open circle) activities were measured in the presence of different concentration of ethanol.

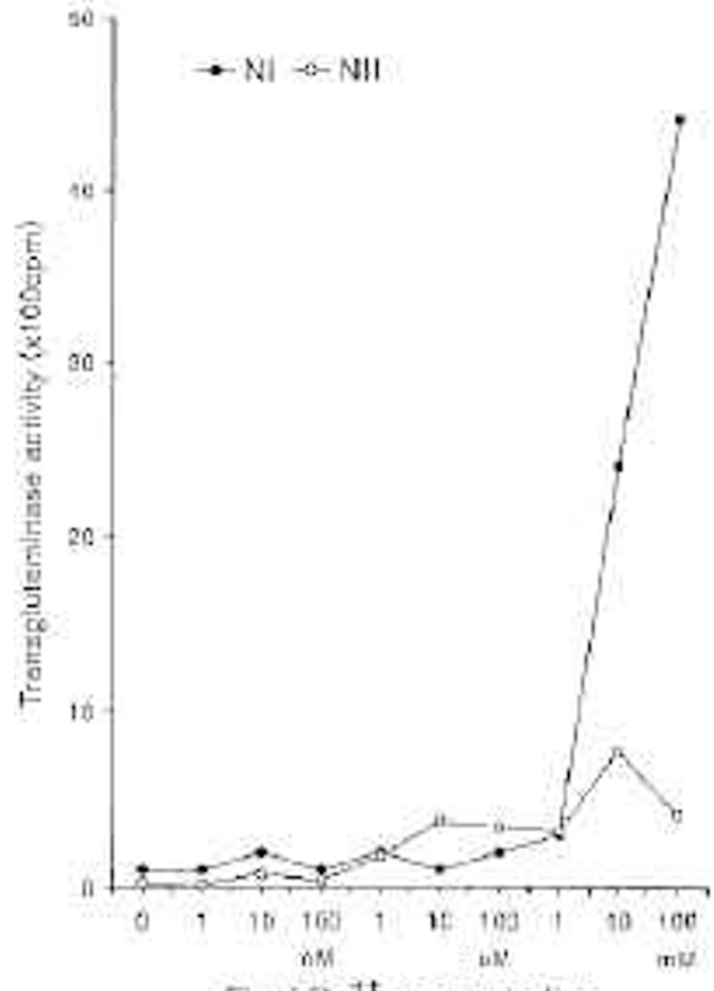

Figure 4. Dependency of $\mathrm{NI}$ and NII TGase activity on calcium concentration. TGase NI (closed circle) and NII (open circle) activities were measured in the presence of different concentration of calcium from $1 \mathrm{nM}$ to $100 \mathrm{mM}$.

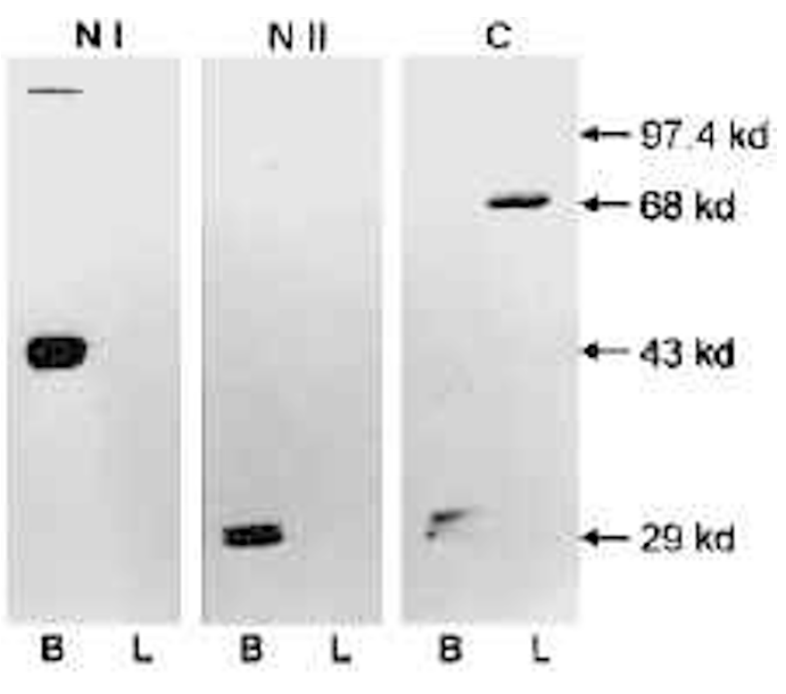

Figure 6. Westernblot analysis of brain and liver tissue homogenates with the TGase type-specific antibodies. B and $\mathrm{L}$ represent for brain and liver homogenate, respectively. Panels NI, NI I and C represent different type-specific antibodies utilized, TGase NI, TGase NII, TGase C, respectively. 


\section{Enzyme properties}

The purified enzyme was very labile, though its purification fold was approximately 200 fold to the control homogenate, it was very difficult to stabilize the enzymic activity, of which TGase NII lost its activity completely after two week storage at $4^{\circ} \mathrm{C}$. The activity staining by dansylcadaverine fluorescence illustrated the TGase activity in the respective protein bands, confirming the enzymic fraction (data not shown). The molecular weights of the enzyme were estimated by SDSpolyacrylamide gel electrophoresis to be $45 \mathrm{kDa}$ for TGase NI and $29 \mathrm{kDa}$ for TGase NII with a minor additional $80 \mathrm{kDa}$ protein (Figure 2). But by wastern blot analysis with the respective antibody, only the $29 \mathrm{kDa}$ protein was detected in TGase NII fraction (Figure 6). Both TGase NI and TGase NII lost their activities by proteolytic attack either of dispase or trypsin (Figure 3) or thrombin (data not shown). TGase NI required $100 \mu \mathrm{M}$ calcium for optimum activity while TGase NII did $10 \mu \mathrm{M}$. Interestingly, the high concentration of $\mathrm{Ca}^{2+}$ over $10 \mu \mathrm{M}$ rather inhibited TGase NII activity (Figure 4). These two types of brain TGases showed different sensitivity to ethanol, that is, TGase NII was more sensitive to ethanol than TGase NI (Figure 5). The $K_{m}$ values of the enzymes toward putrescine were $0.28 \mathrm{mM}$ for TGase NI and $0.17 \mathrm{mM}$ for TGase NII, indicating the high affinity of these enzymes to polyamine. The N-terminal for TGase $\mathrm{NI}$ and TGase NII were blocked.

Western blot analysis revealed that TGase NI and NII were present in brain tissue but not in liver tissue (Figure $6)$. The molecular sizes of the antibody-responsive proteins in the brain homogenate were compatible with the purified enzymes, $45 \mathrm{kDa}$ and $29 \mathrm{kDa}$, respectively. The antibody against TGase $C$ could recognize the intact enzyme in the liver homogenate as well as the probable proteolytic fragment $(30 \mathrm{kDa})$ of TGase $\mathrm{C}$ in the brain homogenate. This result suggested that the TGase NI and NII would be immunologically different from TGase C, and that TGase $\mathrm{C}$ in the brain tissue might be frag-mented.

\section{Immunocytochemical Analysis}

Immunocytochemical analysis showed that both of neuronal cells and astrocytes at 4th and 9th day of culture positively reacted with anti TGase NI, TGase NII antibodies. Both cells were also positive to TGase $C$ antibody. But the anti-TGase NI, and anti-TGase NII antibodies showed the much stronger reaction than anti-TGase $\mathrm{C}$ antibody (Figure 7).

Anti-TGase E antibody showed the very weak but positive response in both types of nerve cells. The cell lines showed the similar pattern of TGase presence. PC12 cell showed positive reaction to anti TGase NI, NII and $\mathrm{C}$ antibodies, while anti TGase $\mathrm{E}$ antibody showed the very weak response (Figure 8). In case of C6 glioma cell, only anti TGase NI and NII antibodies showed the positive response, while anti TGase E and TGase C antibodies reacted negligibly (Figure 9).

\section{Discussion}

Five different types of TGases from the mammalian
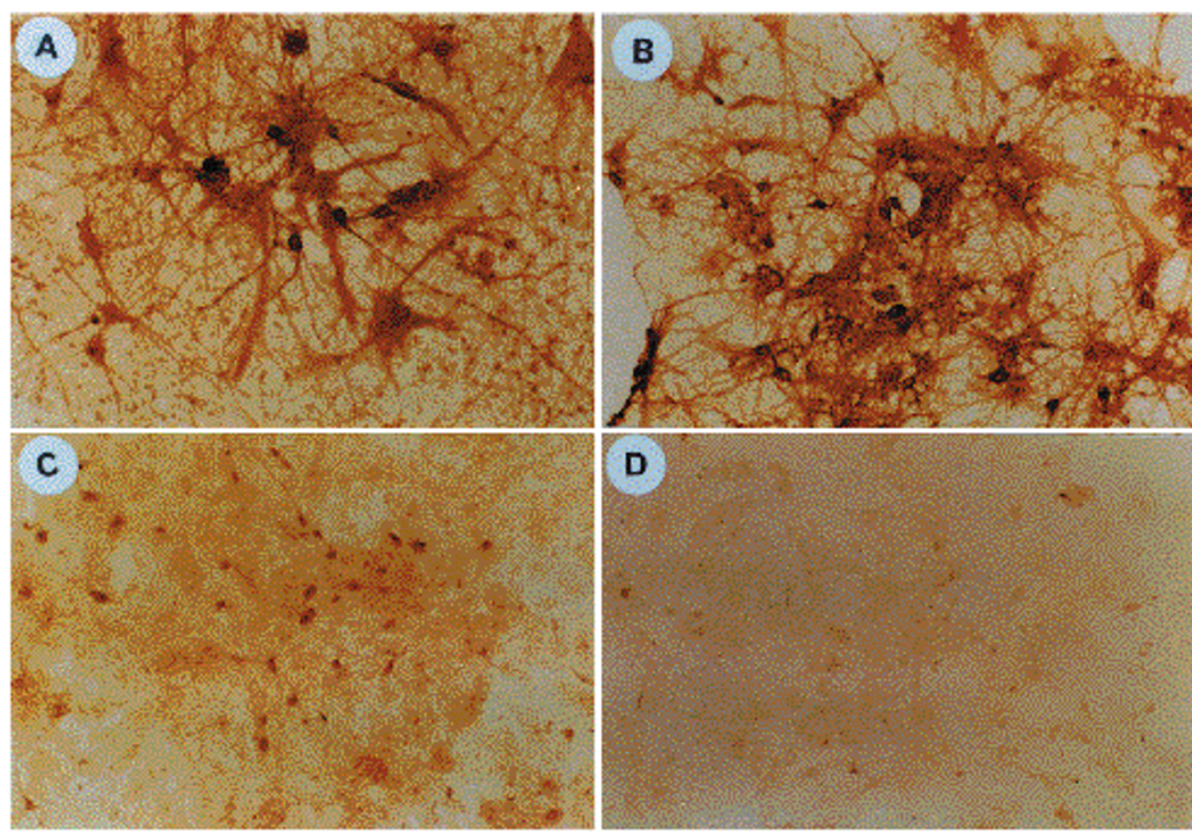

Figure 7. Immunocytochemical staining of neurons and astrocytes cultured from fetal rat brain with the subtypes of TGase. Mesencephalic neurons were cultured from 14 days-old fetal rat brain and immunostained with rabbit polyclonal antibodies specific to subtype of TGase (A, TGase Nl; B, TGase NII; C, TGase C; D, TGase E) as described 'Materials and Methods'. Transglutaminase NI, NII, C were expressed in most of neurons and astrocytes, but TGE was very weakly expressed in these cells. Original magnification $\times 200$. 

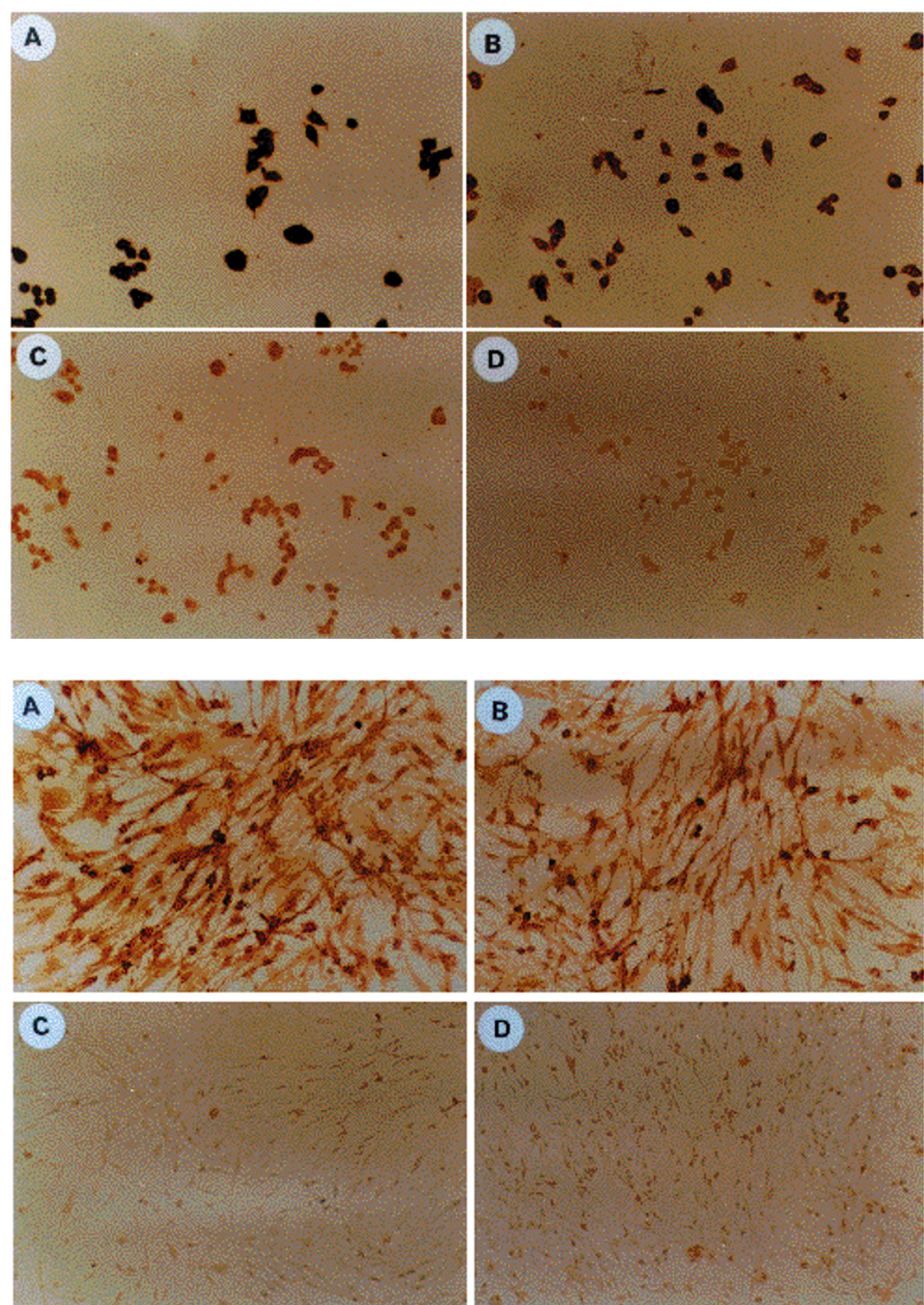

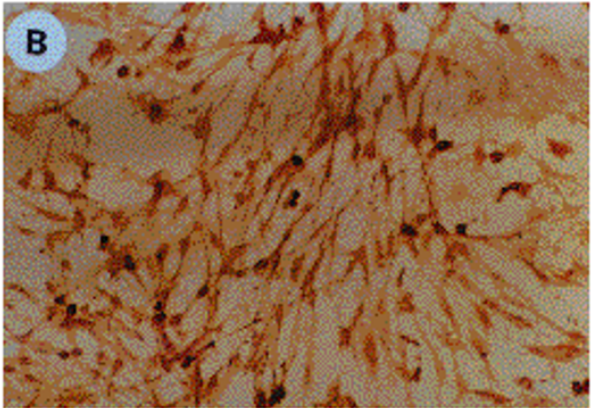

D

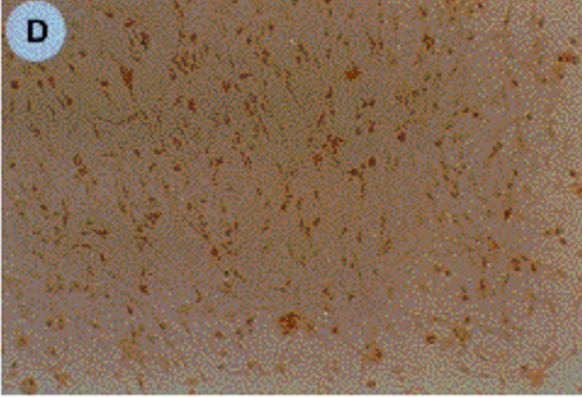

Figure 8. Immunocytochemical staining of PC12 pheochromocytoma cells (cultured for 4 days) with polyclonal antibodies specific to subtype of TGases (A, TGase NI; B, TGase NII; C, TGase C; D, TGase E). Original magnification $\times 200$.
Figure 9. Immunocytochemical staining of $\mathrm{C} 6$ glioma cells with polyclonal antibodies specific to subtypes of TGases (A, TGase Nl; B, TGase NII; C, TGase C; D, TGase E). Original magnification $\times 200$ tissues have been isolated and characterized on their genetic and biochemical properties, such as TGase 1 (keratinocyte TGase, particulate TGase, TGase K), TGase 2 (tissue TGase, liver TGase, cytosolic TGase, TGase C), TGase 3 (epidermal TGase, TGase E), TGase 4 (prostate TGase) and Factor XIII. Each enzyme has been found to be expressed organ-specifically and associated with a variety of biological processes (Folk and Cole, 1966; Takagi and Doolittle, 1974; Thatcher, 1989; Kim et al., 1990; Seitz et al., 1991).
Recently, the probable involvement of a TGase in the neurodegenerative diseases attracted the special concern on several aspects. The devastating Altzheimer's disease might be derived from the crosslinking of the neurofilaments, microtubule-associated tau proteins, or amyloid $\beta$ proteins (Selkoe et al., 1982; Miller and Anderton, 1986; Lorand, 1996). The gene products with polyglutamine tracts whose length is determined by the number of CAG repeats could be the putative substrates for TGase, associated with Huntington's disease, spinocerebellar ataxia 
type I, dentarubral-phallidoluysian atrophy, spinobulbar muscular atrophy and spinocerebeller ataxia type 3 (Cariello et al., 1996; Kahlem et al., 1996). The midkine, a highly basic heparin-binding cytokine, dimerized by a TGase can stabilize the growth factor, endowing its neurite-promoting activity amplification (Mahoney et al., 1986). In contrast, TGase-mediated dimers of interleukin 2, unlike monomer, induce apoptosis in oligodendrocytes (Schwartz, 1993).

These effects of TGase activity in brain disorders are assumed under the presence of the enzyme in the brain tissues, but without success in their isolation and characterization. The induction of neural apoptosis was suggested to be TGase-associated. Transfection of TGase $\mathrm{C}$ gene into neuroblastoma cells sensitized the retinoic acid-induced apoptosis, while that of antisense oligonucleotide to TGase $\mathrm{C}$ caused a pronounced inhibition (Melino et al., 1994). Furthermore, depolarizing agents such as acetylcholine or carbachol, a muscarinic receptor agonist, caused a significant activation of a TGase in superior cervical ganglion, which might be related with nitric oxide (Nagata and Ando, 1994). In the vicinity of acetylcholine receptor, plenty of TGase activities have been observed, probably for receptor aggregation (Hucho and Bandini, 1990). Some of neurotransmitters were posttranslationally modified by polyamine such as substance $P$ and $\beta$-endorphin, which inactivated the respective functions (Porta et al., 1988; Pucci et al., 1988; Kowall et al., 1991; Persico et al., 1992). These activities were functionally increased by neurodifferentiation and develop-ment (Maccioni and Seeds 1986, Gilad and Varon 1985), long-term potentiation of memory (Friedrich et al., 1991), and stimulation by gangliosides or acetylcholine (Ando et al., 1991a, b).

However, most of the studies for TGase-related phenomena in brain or neural cells were carried out by use of TGase $C$ under the assumption that it would be the brain enzyme. Actually, some characteristics of the brain TGase are similar to those of TGase C. Nevertheless, the identity of brain TGase as TGase $C$ has not been confirmed. Several studies to isolate and characterize TGase from brain tissue or nerve cells showed a variety of enzymes, but none have been successfully isolated and characterized. From the pheochromcytoma cells, two types of TGases were suggested (Byrd and Licht 1987), probably of TGase C-like one and TGase E-like one on the basis of elution profile, thermolability and cytosolic localization. And from human brain, erythrocyte TGase (identical to TGase C, tissue TGase)-like enzyme was characterized (Selkoe et al., 1982).

The difficulty of isolating brain TGases might be due either to its instability or extreme low activity. In our preliminary study with electroconvulsive shock, we could observe the temporal and spatial changes in TGase activity, but the activity was very low and unstable to compare with those of other organs (Park, unpublished). With aging process, the enzymic activity was increased in brain tissue, indicating the possible involvement of the enzyme in neurodegenerative changes associated with senescence (Park et al., paper submitted)

In the present experiment, we also experienced the difficulty in maintaining the stability of the enzyme for purification. The brain TGases isolated partially in the present study, however, showed the some different characteristics from other types of previously known TGases (Figure 1, 2). The sensitivities of the enzyme to proteases such as thrombin, dispase or trypsin were similar to those of TGase $C$ but totally different from those of TGase E and Factor XIII (Figure 3). Between TGase $\mathrm{NI}$ and $\mathrm{NII}$, the sensitiviies to protease or ethanol and $\mathrm{Km}$ values toward putrescine were different (Figure 5). The elution profiles from DEAE- cellulose chromatography of brain TGases were different from other TGases (Figure 1). TGase NI fraction was eluted at $0.35 \mathrm{M}$ $\mathrm{NaCl}$, while TGase NII fraction at $0.28 \mathrm{M} \mathrm{NaCl}$. But the other TGases showed the distinct elution profiles ; TGase $\mathrm{K}$, at $0.2 \mathrm{M} \mathrm{NaCl}$; TGase $\mathrm{C}$ at $0.3 \mathrm{M} \mathrm{NaCl}$; TGase E, at $0.05 \mathrm{M} \mathrm{NaCl}$ (Goldsmith and Martin, 1975; Chung, 1986; Park, 1988). And the elution behavior of brain TGases in washing fraction from CM-cellulose chromatography indicated that the enzymes might be negatively charged. But amino acid sequence analysis could not identify the $\mathrm{N}$ terminal amino acids, probably because of $\mathrm{N}$ terminal block of the enzyme. Moreover, the immunologic properties of TGase NI and NII were distinct from TGase C, TGase E and Factor XIII. As shown in Figure 6, antibodies to TGase NI and NII recognized the brain-specific TGases, while antibody to TGase $C$ would detect liver TGase $C$ and the probable proteolytic fragment of TGase $C$ in the brain tissue. The unique tissue distribution pattern of TGase $\mathrm{NI}$ and TGase NII again illustrated the specificity of the enzyme as the brain TGases (Figure 6). TGase NI and TGase NII were localized only to brain tissue but not to liver tissue, while the amount of TGase $C$ in brain tissue was very restricted or the enzyme could be in proteolytic form to be compared with that in liver tissue. The presence of the unique TGase in the brain tissue would attract the special concern for the role of enzyme in the neural system. In addition, the proteolytic fragment responsive to anti TGase $C$ antibody would explain the biochemical difficulty in identification of TGase $\mathrm{C}$ as the brain enzyme.

The immunocytochemical analysis with the respective antibody showed that TGase NI localized at processbearing and polygonal neuronal cells of rat brain-derived primary nerve cell culture, while TGase NII localized mostly at process-bearing neurons (Figure 7, 8 and 9). Also in the previous studies, TGase activity was present ubiquitously in all the fractions of brain tissue, but at the 
synaptosomal fraction, the highest activity was detected (Gilad and Varon, 1985, Pastuszko et al., 1986, Korner and Bachrach, 1987, Reichelt and Poulsen, 1992, Campisi et al., 1992).

In most of TGase work with brain or neural system, the crosslinking activity has been focused for its probable association with neurodegeneration and apoptosis. For that work, it is very important to identify the brain-specific TGases and to characterize their regulatory mechanism and natural physiological substrates. If the $\beta$ amyloid protein, microtubule- associated proteins, neurofilaments or the polyglutamine-rich neural proteins were identified to be the biological substrates for brain-specific TGases the drugs for the various neurodegenerative diseases would be developed from the specific inhibitors to brain TGases. Moreover, the TGase activity increase by tetanus or botulinum toxin was suggested to be a mechanism of neurotoxicity by blocking exocytosis of the neurotransmitters (Facchiano and Luini, 1992), important for to development of antineurotoxic drugs.

In addition to crosslinking activity, the enzyme has some other properties such as GTP binding and GTP hydrolysing activities, which are closely related with the signal transduction system (Lee et al., 1989). In cardiac myocyte, TGase $\mathrm{C}$ was identified to be $\mathrm{G}$ protein mediating the $\alpha 1$ adrenergic receptor signal to phospholipase $C$ (Nakaoka et al., 1994). But this activity was found to be independent of crosslinking activity of the enzyme from active-site mutant analysis.

Moreover, the TGase-gene transfected cell showed the delaying at the progression of cell cycle from $S$ phase to G2/M phase, connoting the role of TGase in cell cycle control. But the cell cycle control activity of the enzyme was found not to be associated with its crosslinking activity, either. These results strongly suggested that TGase protein has another important cellular regulatory function apart from its crosslinking act ivity. Therefore, it is important to consider the role of the TGase protein in the biological phenomenon not necessarily as the crosslinker but as the non-crosslinking cellular modulator.

This additional activity of TGase as a signal transducer stimulated us to consider TGase protein as an active regulatory molecule for cell cycle and signal transduction. The latter function of the enzyme would solve many mysteries concerning its high appearance in growth factor stimulated proliferating phase, endogenous high level of expression in endothelial and smooth muscle cells, and its active role for cellular survival with drugresistence toward toxic compounds, etc, which could not be readily explained in terms of crosslinking of the proteins (Park et al., 1994).

In conclusion, we have isolated novel brain TGases, which are different from other types of TGases in biochemical and immunological properties, and have confirmed its localization in neural cell and brain tissues. For the analysis of their physiological roles, it is required to investigate the mechanism of the enzyme with multiple functional aspects not only from macromolecular modification or stabilizing activity from its crosslinking ability, but also from signal transducing activity from GTP binding or GTP hydrolyzing property and cell cycle controlling activity.

\section{Acknowledgement}

This work was supported by the grants from Seoul National University College of Medicine, the Korea Research Foundation for Health Science.

\section{References}

Ambron, R. T. and Kemzner, L. T. (1982) Posttranslational modification of neuronal proteins : evidence for transglutaminase activity in R2, the giant cholinergic neuron of Aplysia. Proc. Natl. Acad. Sci. USA 79: 3442-3446

Ando, M., Nakashima, Y. and Nagata, Y. (1991a) Stimulation by acetyl-choline and inhibition by norepinephrine of transglutaminase activity in superior cervical ganglia excised from adult rats. Nenrosci. Res. 12: 356-365

Ando, M., Nakashima, Y. and Nagata, Y. (1991b) Stimulation of transglu-taminase activity by $\mathrm{GMI}$-gangliosides and $\alpha$-sialocholesterol in superior cervical and nodose ganglia excised from adult rat. J. Neurochem. 57: 1848-1854

Ando, M., Tatematsu, T., Kunii, S. and Nagata, Y. (1994) Blockade effect of nerve growth factor on GMI ganglioside-induced activation of trans-glutaminase in superior cervical sympathetic ganglia excised from adult rat. Necurosci. Res. 19: 373-378

Byrd, J. C. and Licht, U. (1987) Two types of transglutaminase in the PC12 pheochromocytoma cell line : stimulation by sodium butyrate. J. Biol. Chem. 262(24): 11699-11705

Campisi, A., Renis, M., Russo, A., Sorrenti, V., Di Giacomo, C., Castorina, C. and Vanella, A. (1992) Transglutaminase activity in primary and subcultured rat astroglial cells. Neurochem. Res. 17: 1201-1205

Cariello, L., Cristofaro, T. D., Zanetti, L., Cuomo, T., Maio, L. D., Campanella, G., Rinaldi, S. Zanetti, P., Lauro, R. D. and Varrone, S. (1996) Trans-glutaminase activity is related to CAG repeat length in patients with Huntington's disease. Hum. Genet. 98: 633-635

Dudek, S. M. and Johnson, G. V. (1993) Transglutaminase catalyzes the formation of SDS-insoluble Alz 50-reactive polymers of tau. J. Neurochem. 61: 1159-1162

Eitan, S. and Schwartz, M. (1993) A transglutaminase that converts interleukin-2 into a factor cytotoxic to oligodendrocytes. Science 261: 106-108

Facchiano, F and Luini, A. (1992) Tetanus toxin potently stimulates tissue transglutaminase: a mechanism of neurotoxicity. J. Biol. Chem. 267(19): 13267-13271

Folk, J. E. and Chung, S. I. (1985) Transglutaminases. Methods Enzymol. 113: 358-375

Folk, J. E. and Cole, P. W. (1996) Mechanism of action of guinea pig liver transglutaminase. J. Biol. Chem. 241: 5518-5529

Friedrich, P., Fesus, L., Tarsa, E. and Czeh, G. (1991) Protein crosslinking by transglutaminase induced in long-term potentiation in the CAI region of hippocampal slices. Neuroscience 43: 331-334

Gilad, G. M. and Varon, L. E. (1985) Transglutaminase activity in rat brain: characterization, distribution and changes with age. J. Neurochem. 45: 1522-1526

Goldsmith, L. A. and Martin, G. M. (1995) Human epidermal transglu-taminase. J. Invest. Dermatol. 64: 316-321 
Gray, M. H., Smoller, B. R., McNutt, N. S. and Hsu, A. (1990) Immuno-histochemical demonstration of factor XIII a expression in neurofibromas. Arch. Dermatol. 126: 472476

Hucho, F. and Bandini, G. (1986) $\mathrm{Ca}^{2+}$ dependent inactivation of acetyl-choline receptors by an endogenous transglutaminase. FEBS Lett. 200: 279-282

Ikura, K., Takahara, K. and Sasaki, R. (1993) Crosslinking of a synthetic patial length(128) peptide of Altzheimer B/A4 amyloid protein by trans-glutaminase. FEBS Lett. 326 109-111

Kahlem, P., Terre, C., Green, H. and Djian, P. (1996) Peptides containing glutamine repeats as substrates for transglutaminase-catalyzed cross-linking: Relevance to diseases of the nervous system. Proc. Natl. Acad. Sci. USA 93: 14580-14585

Kim, H. C., Lewis, M. S., Gorman, J. J., Park, S. C., Girad, J. E., Folk, J. E. and Chung, S. I. (1990) Protransglutaminase E from guinea pig skin, J. Biol. Chem. 265: 2197121978

Korner, G. and Bachrach, U. (1987) Intracellular distribution of active and inactive transglutaminase in stimulated cultured C6 glioma cells. J. Cell. Physiol. 130: 44-50

Kowall, N. W., Beal, M. F., Busciglio, J., Duffey, L. K. and Yanker, B. A. (1991) An in vivo model for the neurodegenerative effects of $\beta$-amyloid and protection by substance $P$. Proc. Natl. Acad. Sci. USA 88: 7247-7251

Lee, K. N., Birckbichler, P. J. and Patterson, M. K. Jr. (1989) GTP hydrolysis by guinea pig liver transglutaminase. Biochem. Biophys. Res. Comm. 162: 1370-1375

Lorand, L. (1996). Neurodegenerative diseases and transglutaminase. Proc. Natl. Acad. Sci. USA 93: 14310-14313

Maccioni, R. B. and Seeds, N. W. (1986) Transglutaminase and neuronal differentiation. Mol. Cell Biochem. 69: 161-168

Mahoney, S. A., Perry, M., Seddon, A., Bohlen, P. and Haynes, L. (1996) Transglutaminase forms midkine homodimers in cerebellar necuons and modulates the neurite-outgrowth response. Biochem. Biophy. Res. Comm. 224: 147-152

Melino, G., Annicchiarico-Petruzzelli, M., Piredda, L., Candi, E., Gentile, V., Davies, P. J. A. and Piacentini, M. (1994) Tissue transglutaminase and apoptosis: sense and antisense transfection studies with human neuroblastoma cells. Mol. Cell. Biol. 14(10): 6584-6596

Miller, C. C. J. and Anderton, B. H. (1986) Transglutaminase and the neuronal cytoskeleton in Altzheimer's disease, J. Neurochem. 46: 1912-1922

Nakaoka, H., Perez, D. M., Baek, K. J., Das, T., Husain, A., Misono, K., Im, M. J. and Graham, R. M. (1994) Gh: a GTP-binding protein with transglutaminase activity and ras signaling function. Science 264: 1593-1596

Park, S. C., Kim, W. H., Lee, M. C., Seong, S. C., Song, K. Y. and Choe, M. A. (1994) Modulation of transglutaminase expression in rat skeletal muscle by induction of atrophy and endurance training. J. Kor. Med. Sci. 9: 490-497

Paschen, W., Rohn, G., Schmidt-Kastner, S. (1990) Transglutaminase activity in reversible cerebral ishemia in the rat. Neurosci. Lett. 110: 232-236

Pastuszko, A., Wilson, D. F. and Erecinska, M. (1986). A role for trans-glutaminase in neurotransmitter release by rat brain synaptosome. J. Neurochem. 46: 499-508
Persico, P., Calignano, A., Fancuso, F., Marino, G., Pucci, P., Esposito, C., Mariniello, L. and Porta, R. (1992) Substance $P$ inactivation by transglutaminase in vivo. Peptides 13: 151-154

Porta, R., Esposito, C., Metafora, S., Pucci, P., Malorni, A. and Marino, G. (1988) Subsrtance $P$ as a transglutaminase substrate: identification of the reaction products by fast atom bombard ment mass spectrometry. Anal. Biochem. 172: 499-503

Pucci, P., Malorni, A., Marino, G., Metafora, S., Esposito, C. and Porta, R. (1988) $\beta$ endorphin modification by transglutaminase in vitro: identi-fication by FAB/MS of glutamine-11 and lysine-29 as acyl donor and acceptor sites. Biochem. Biophys. Res. Comm. 154: 735-740

Rasmussen, L. K., Sorenson, E. S., Peterson, T. E., Glieman, J., Jensen, P. H. (1994) Identification ofglutamine and lysine residues in Alzheimer amyloid beta A4 peptide responsible for transglutaminase catalyzed homopolymerization and crosslinking of $\alpha 2 \mathrm{M}$ receptor. FEBS Lett. 358, 161-166

Reichelt, K. L. and Poulsen, E. (1992) $\gamma$-Glutamylaminotransferase and transglutaminase in subcellular fractions of rat cotex and in cultured astrocytes. $J$. Neurochem. 59: 500-504

Ross, C. A. (1995) When more is less: pathogenesis of glutamine repeat neurodegenerative diseases. Neuron 15: 493-496

Seitz, J., Keppler, C., Huntemann, S., Rausch, U. and Aumuller, G. (1991) Purification and molecular characterization of a secretory transglutaminase from coagulating gland of the rat. Biochim. Biophys. Acta. 1078: 139-146

Selkoe, D. J., Abraham, C. and Ihara, Y. (1982) Brain transglutaminase: In vitro crosslinking of human neurofilament proteins into insoluble poly-mers. Proc. Natl. Acad. Sci. USA. 79: 6070-6074

Takagi, T. and Doolittle, R. F. (1974) Amino acid sequence studies on factor XIII and the peptide released during its activation by thrombin. Biochemistry 13: 750-756

Thacher, S. M. (1989) Purification of keratinocyte transglutaminase and its expression during squamous differentiation. J. Invest. Dermatol. 92: 578-584.

Whang, K. C., Gray, C. D., Sivasubramanian, N. and Im, M. J. (1995) Interaction site of GTP binding Gh(transglutaminase II) with phospholipase C. J. Biol. Chem. 270: 2715827062 